\title{
Isolation of the wild-type rubella virus in rabbit kidney cell line RC-IAL
}

\author{
Isolamento do vírus selvagem da rubéola na linhagem celular de rim de coelho RC-IAL
}

Cristina A. Figueiredo; Maria I. Oliveira; Ana M. S. Afonso; Márcia Theobaldo; Aurea S. Cruz; Suely P. Curti

\begin{tabular}{l|l}
\multicolumn{1}{c|}{ key words } & abstract \\
\hline Rubella virus & $\begin{array}{l}\text { The present study describes the isolation and growth the wild-type rubella virus in RC-IAL. The } \\
\text { susceptibility of a rabbit kidney (RC-IAL) to the RV RA } 27 / 3 \text { strain was previously reported by us }{ }^{(4)} \text {. } \\
\text { Samples of } 20 \text { patients with suspected cases of rubella infection were tested by serology, virus isolation } \\
\text { and nested PCR. The sera were tested by Elisa for the detection of rubella virus antibodies and nested } \\
\text { Cell line }\end{array}$ \\
$\begin{array}{l}\text { PCR assay was performed to detect RNA virus. The samples of urine, blood, fragments of placenta and } \\
\text { amniotic fluid were inoculated in the RC-IAL (rabbit kidney, Institute Adolfo Lutz) and SIRC (rabbit cornea) } \\
\text { cell lines. Rubella virus was isolated in samples from } 14 \text { of the patients. The CPE (cytopathic effect) was } \\
\text { visualized by phase contrast and RV RNA was amplified by nested PCR. The results obtained showed that } \\
\text { the cellular lineage RC-IAL is an excellent substratum for isolation of the rubella virus. These findings are } \\
\text { important since this is one the few cell lines described in literature that presents a cytopathic effect, so } \\
\text { that it can be used to isolate the virus of the clinical specimens. }\end{array}$
\end{tabular}

resumo

O presente estudo descreve o isolamento e o crescimento do vírus selvagem da rubéola na linhagem celular RC-IAL. A susceptibilidade da linhagem celular RC-IAL (rim de coelho, Instituto Adolfo Lutz) para o vírus-padrão da rubéola RA 27/3 foi anteriormente descrito por nós(4). Amostras de 20 pacientes com suspeita de infecção por rubéola foram testadas por sorologia, isolamento viral e nested $P C R$. Os soros foram testados por Elisa para detecção de anticorpos reagentes para rubéola e nested PCR para detectar o RNA viral. As amostras clínicas de sangue, urina, fragmento de placenta e líquido amniótico foram inoculadas nas linhagens celulares $R C-I A L$ (rim de coelho, Instituto Adolfo Lutz) e SIRC (córnea de coelho). O vírus da rubéola foi isolado das amostras clínicas de quatorze pacientes. O efeito citopático (ECP) foi examinado por microscopia de contraste de fase, e o RNA do vírus da rubéola foi amplificado por nested PCR. Os resultados obtidos mostram que a linhagem celular RC-IAL é um excelente substrato para isolamento do vírus da rubéola. Estes dados são importantes, pois poucas linhagens descritas na literatura apresentam efeito citopático que possibilite seu uso para isolar o vírus da rubéola de material clínico.

\section{unitermos}

Vírus da rubéola

Isolamento

Linhagem celular

Efeito citopático 


\section{Introduction}

Rubella is generally a mild disease with few complications. However, when acquired in the first 12 weeks of pregnancy, it usually results in congenital infection associated with one or more severe defects in $80 \%$ to $90 \%$ of the cases. Rubella has almost been eradicated by immunization programs in many developed countries, but outbreaks amongst the unvaccinated still occur ${ }^{(12,14)}$.

Monolayer cell culture in tubes has been used for the isolation of viruses since Enders et al. (1949) first reported the growth of poliovirus in various human embryonic tissues. The method remains the gold standard for the diagnosis of many viruses and the technique against which newer technologies are measured ${ }^{(2)}$.

The routine diagnosis of rubella virus (RV) infections is based on detection of RV-specific IgM in serum, isolation of rubella virus in cell culture and nested PCR. Rubella virus may be isolated from nasopharyngeal swabs, blood, urine, cerebrospinal fluid or tissues obtained by biopsy, autopsy or surgical procedures ${ }^{(9)}$. RV replicates in a variety of cell culture systems, primary cells and continuous cell lines $(1,7,9,10,11,13)$. The presence of rubella virus indicated by the typical cytopathic effect (CPE) in infected cells is, however, difficult and laborious to detect. When the conditions are carefully controlled, a certain degree of cytopathic effects is observed in some continuous cell lines and some sub-lines(11, 13, 15, 16).

The virus isolation for the diagnosis permits the detection of a wide variety of virus types including new or antigenic variants of known viruses. Increasing the number of cell lines routinely used is recognized to lead to an increased number of virus isolates, and thus it improves the sensitivity of the employed virus isolation system ${ }^{(6,17)}$.

This report describes the isolation of the rubella virus samples in RC-IAL (rabbit kidney established in Instituto Adolfo Lutz) with the development of a cytopathic effect, in response to infection by the rubella virus.

\section{Material and method}

\section{Specimens}

Twenty samples (sera, blood, urine, amniotic fluid and fragment of placenta) with clinical history suggestive of rubella virus were used in this study. There were eleven samples of peripheral blood, nine of urine, one of amniotic fluid and one fragment of placenta.
The peripheral blood lymphocytes were separated from heparinized blood with ficoll-hypaque gradients and suspended in DMEM (medium modified Dulbecco's) supplemented by $2 \%$ fetal calf serum.

The amniotic fluid was obtained from a woman with acute rubella infection and about 20 weeks of gestation and the fragment of placenta from a woman in the second trimester of pregnancy.

The fragment of placenta was ground in DMEM containing antibiotic (gentamicin, $40 \mu \mathrm{g} / \mathrm{ml}$ ) and was shaken vigorously by hand for a few minutes and then centrifuged at $1.000 \mathrm{rpm}$ for five minutes at $4^{\circ} \mathrm{C}$. The supernatant fluid was removed and stored at $-70^{\circ} \mathrm{C}$.

\section{Serologic studies}

The assay used for the detection of RV antibodies was the Rubenostika IgM II microelisa system (Organon Teknika, Boxtel, NL) following the manufacturers' instructions.

\section{Virus growth}

The RC-IAL and SIRC (ATCC CCL 60) cell lines containing $1 \times 10^{6}$ cells $/ \mathrm{ml}$ were grown in T25 flasks in DMEM supplemented with $10 \%$ inactive fetal calf serum (FCS), $20 \mathrm{mM} \mathrm{L-glutamine}$. The confluent cells were inoculated with $0.5 \mathrm{ml}$ of each sample for one hour at room temperature. After one hour, each cell line received $5 \mathrm{ml}$ of medium with $2 \%$ FCS and was incubated at $37^{\circ} \mathrm{C}$. The medium was replaced every three days. Cell cultures were observed for CPE daily during seven days. Samples with no CPE after two passages were discarded as negative for virus isolation. If CPE was observed, the cells were harvested by centrifugation and RNA was extracted from the cell pellet. Uninfected cultures were also prepared and treated identically as positive controls.

\section{Virus stock}

The rubella virus RA 27/3 strain (Meruvax II, Merck, Sharp and Dohme) was grown in SIRC and RC-IAL cells. The cells containing $1 \times 10^{6}$ cells were grown in T25 flasks in DMEM with $10 \%$ FCS and infected with $0.5 \mathrm{ml}$ of the RA 27/3 virus strain. The cells were maintained in DMEM supplemented with $2 \%$ fetal calf serum, $20 \mu \mathrm{M}$ L-glutamine. For the virus stock, three passages were performed on cell cultures.

\section{Nested PCR assay}

The samples - serum, peripheral blood lymphocytes, urine, amniotic fluid, fragment of placenta and culture- 
inoculated supernatants - were individually snap-frozen in plastic vials and stored at $-70^{\circ} \mathrm{C}$. RNA was extracted from the entire cell pellet by the guanidinium isothiocyanate method and submitted to reverse transcriptase-PCR (RT-PCR) followed by nested PCR as described by Best ${ }^{(2)}$.

\section{Results}

The twenty samples from the patients with suspected cases of rubella infection were tested by serology, virus isolation and nested PCR.

Rubella specific immunoglobulin (IgM) response was detected in seven of the 11 samples tested. The same results were obtained by nested PCR. The serum sample from patient number 3 was negative by serology and nested $\mathrm{PCR}$, probably because it was obtained $<3$ days after rash onset. However, this case was confirmed by positive virus isolation (Table).
The samples - blood, urine, amniotic fluid and placenta - were inoculated in RC-IAL and SIRC cells and incubated for seven days. Rubella virus was isolated in samples from fourteen patients (Table). Uninoculated control cultures of RC-IAL cell line showed a monolayer of densely packed fibroblastic cells. Cells inoculated with samples showed CPE in both cell lines at the first passage (Figure). The CPE was characterized by an increased cellular refraction and a rounding of infected cells. The first morphological changes were observed in 48 hours after inoculation of the rubella virus and they spread to complete infection by the seventh day. The CPE in RC-IAL and SIRC cell lines was observed at $25 \%$ in the first 48 hours and $50 \%$ after 96 hours. These changes were widespread over large areas of the sheet, with the culture remaining intact, and almost maintained the integrity of the cell sheet. On the second passage, cytopathic effects became detectable on the second and third days, respectively. The RC-IAL cells

Table Comparative laboratory findings in children and young adults with rubella virus

\begin{tabular}{|c|c|c|c|c|c|c|c|c|}
\hline \multirow{3}{*}{ Patient } & \multirow{3}{*}{ Sample } & \multirow{3}{*}{ Age $(y) / \operatorname{sex}$} & \multirow{3}{*}{$\begin{array}{c}\text { Time between } \\
\text { clinical symptoms/ } \\
\text { collect the sample (days) }\end{array}$} & \multicolumn{5}{|c|}{ Results for rubella } \\
\hline & & & & \multicolumn{2}{|c|}{ Samples } & \multicolumn{3}{|c|}{ Cellular culture } \\
\hline & & & & IgM EIA & PCR & RC-IAL & SIRC & PCR \\
\hline 1 & af & $24 / f$ & - & - & pos & pos & pos & pos \\
\hline 2 & blood & $3 / \mathrm{m}$ & 3 & pos & pos & pos & pos & pos \\
\hline 3 & blood & $1 / f$ & 2 & neg & neg & pos & pos & pos \\
\hline 4 & placenta & $20 / \mathrm{f}$ & - & - & pos & pos & pos & pos \\
\hline 5 & blood & $16 / \mathrm{m}$ & 5 & neg & neg & neg & neg & neg \\
\hline 6 & blood & $20 / \mathrm{m}$ & 5 & pos & pos & pos & pos & pos \\
\hline 7 & blood & $30 / f$ & 4 & pos & pos & pos & pos & pos \\
\hline 8 & urine & $13 / f$ & 3 & - & neg & neg & neg & neg \\
\hline 9 & urine & $5 / f$ & 4 & - & neg & neg & neg & neg \\
\hline 10 & blood & $8 / f$ & 4 & pos & pos & pos & pos & pos \\
\hline 11 & blood & $24 / \mathrm{m}$ & 3 & pos & pos & pos & pos & pos \\
\hline 12 & urine & $25 / \mathrm{f}$ & 4 & - & neg & neg & neg & neg \\
\hline 13 & blood & $20 / \mathrm{m}$ & 3 & neg & neg & neg & neg & neg \\
\hline 14 & blood & $23 / \mathrm{m}$ & 4 & neg & neg & neg & neg & neg \\
\hline 15 & blood & $27 / \mathrm{m}$ & 5 & pos & pos & pos & pos & pos \\
\hline 16 & urine & $23 / \mathrm{m}$ & 4 & - & pos & pos & pos & pos \\
\hline 17 & urine & $15 / \mathrm{m}$ & 3 & - & pos & pos & pos & pos \\
\hline 18 & urine & $28 / \mathrm{m}$ & 4 & - & pos & pos & pos & pos \\
\hline 19 & urine & $27 / \mathrm{m}$ & 3 & - & pos & pos & pos & pos \\
\hline 20 & blood & $34 / \mathrm{f}$ & 3 & pos & pos & pos & pos & pos \\
\hline
\end{tabular}

af: amniotic fluid; pos: positive; neg: negative. 
infected with samples were processed by nested PCR and the product visualized in $2 \%$ agarose stained with ethidium bromide, and had an expected length of 243 base pairs (Table). Concordant results were obtained for fourteen of the samples tested by both techniques (isolation and nested PCR).

The positive control was the RNA extracted from Vero cells infected with the RV (RA 27/3) strain. The negative controls were samples previously shown to be negative by serology and nested PCR.

The results show that the RC-IAL cells are permissive to rubella virus infection, cytopathic effect and production of viral RNA detected by nested PCR.

\section{Discussion}

The cell line of rabbit kidney (RC-IAL) isolated in 1976 at Instituto Adolfo Lutz consisted morphologically of elongated fibroblast-like cells, which form good, well-maintained monolayers ${ }^{(3)}$. The RC-IAL has been studied by Figueiredo ${ }^{(4)}$, showing clearly the CPE when inoculated with the rubella virus RA $27 / 3$ strain.

The present report describes the growth and infection of the rubella virus in the RC-IAL cell line inoculated with samples, in comparison with SIRC cells. All specimens were collected from clinically symptomatic cases and the diagnosis was confirmed by serology.

Analysis of the samples from patients suspect of rubella virus by serology and nested PCR gave 100\% correlation with rubella virus isolation in the cells RC-IAL and SIRC. In one case, sample number 3 in which rubella infection was not identified by RT-PCR, the virus was isolated in cell culture.

The RC-IAL infected cells showed increased cellular refraction and rounding. The morphological changes were observed in 48 hours after inoculation of the samples in response to rubella virus infection. In the first passage the CPE was detected by the seventh day and on the second passage CPE was detected on the second and third days, respectively. The results are in agreement with Phillips and Burkhardt ${ }^{(13)}$ that cell culture of rabbits is permissive to the growth of rubella virus.

The growth of rubella virus in the samples of patients 1 and 4 in the two cell lines and nested PCR positive shows that the use of two methods is important for confirmation of congenitally acquired rubella and for the determination of the duration of virus excretion in such infants with congenital rubella. As the clinical diagnosis of rubella is unreliable, rapid laboratory diagnosis of rubella in pregnancy is critical. The risk of congenital infection may usually be estimated by establishing the gestational age at the time of maternal infection. However, it may be useful to attempt prenatal diagnosis of intrauterine infection under circumstances in which the risk is difficult to establish, such as when there is no history of rash in the mother, maternal serology is inconclusive, infection has occurred between 13 and 20 weeks of gestation or when maternal reinfection is confirmed or suspected in the first trimester ${ }^{(2,8,17)}$.
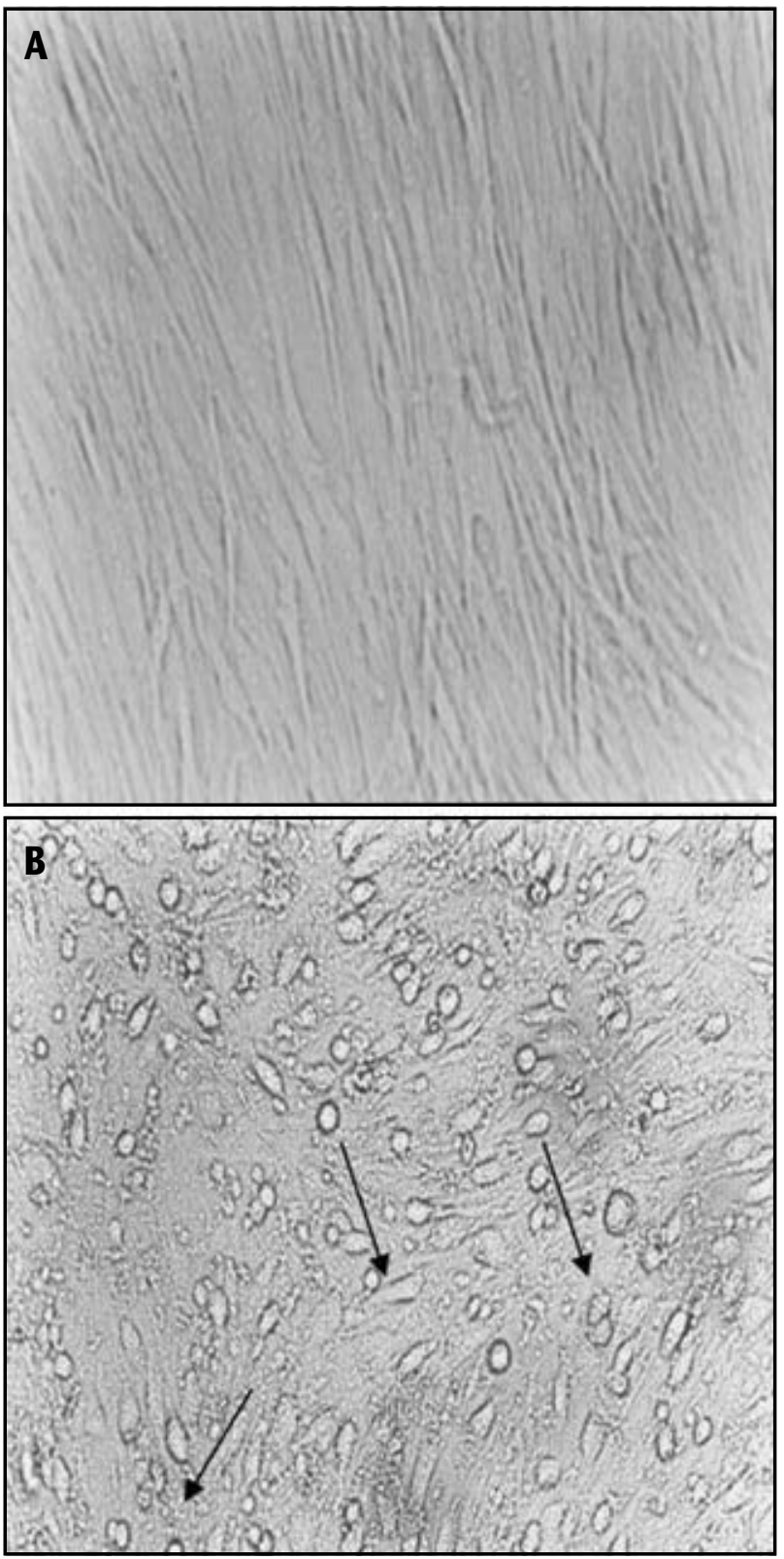

Figure - A: Phase contrast image of monolayer cultures of the RC-IAL cell line; B: Phase contrast images of monolayer cultures of RC-IAL cell line five days after infection with a fragment of the placenta. The rubella CPE was characterized by an increased cellular refraction and a rounding of infected cells (100x) 
Our results demonstrated that RC-IAL cells are permissive to isolated rubella virus and offer several advantages: they are a continuous cell line easily maintained in the laboratory, they produce direct CPE and their isolation procedure is extremely valuable for molecular epidemiology studies as a rapid and convenient method for obtaining field isolates.

\section{References}

I. BELCOURT, R. J. et al. Growth of rubella virus in rabbit fetal tissues and cell cultures. Can J Public Health, v. 56, p. 253-4, 1965.

2. BEST, J. M.; O'SHEA, S. Rubella virus. In: LENNETTE, E.H.; SCHMIDIT, N.J. (ed). Diagnostic procedures for viral, rickettsial and chlamydial infections. $7^{\text {th }}$ ed. Washington, DC: American Public Health Associations, 1995. p. 583-600.

3. CRUZ, A. S. et al. RC-IAL: rabbit kidney cell line: characteristics and substrate for viral multiplication. Rev Saud Pub, v. 26, n. 6. p. 392-9, 1992.

4. FIGUEIREDO, C. A. et al. RC-IAL cell line: sensitivity of rubella virus growth. Rev Saud Pub, v. 34, n. 4, p. 353-7, 2000.

5. ENDERS, J. F.; WELLER, T. H.; ROBBINS, F. C. Cultivation of the Lansing strain of poliomyelitis virus in cultures of various human embryonic tissues. Science, v. 109, p. 85-7, 1949.

6. FONG, C. K. Y; LANDRY, M. L. Advantages of multiple cell culture systems for the detection of mixed virus infections. J Virol Methods, v. 33, p. 283-90, 1991.

7. FREY, K. T. Molecular biology of rubella virus. Adv Virus Res, V. 44, p. 69-160, 1994.

8. FREY, K. T. Neurological aspects of rubella virus infection. Intervirology, v. 40, p. 167-75, 1997.

9. LENNETTE, E. H.; SCHMIDT, N. J. Rubella virus diagnostic procedures for viral rickettsial and chlamydial. $7^{\text {th }}$ ed. Washington, DC:American Public Health Association, 1995. p 583-600.
I0. LIEBHABER, H.; RIORDAM, J. T.; HORSTMANN, D. M. Replication of rubella virus in a continuous line of African green monkey kidney cells (Vero). Proc Soc Exp Bio Med, v. 125, p. 636-43, 1967.

I I. McCARTH, K.; TAYLOR, R. C. H.; PILLINGER, S.E. Isolation of rubella virus from cases in Britain. Lancet, v. 2, p. 593-8, 1963.

12. MILLER, C.L. Rubella in developing world. Epidemiol Infect, v. 107, p. 63-8, 1991.

13. PHILLIPS, C. A.; MELNICK, L.J.; BURKHARDT, M. Isolation, propagation and neutralization of rubella virus in cultures of rabbit cornea (Sirc) cells. Proc Soc Exp Biol Med, v. 122, p. 783-6, 1966.

14. REEF S. E. et al. The changing epidemiology of rubella in the 1990s: on the verge of elimination and new challenges for control and prevention. JAMA, v. 287, n. 4, p. 464-72, 2002.

15. RHIM, J. S.; SCHELL, K. Cytopathic and plaque assay of rubella virus in cultures of rabbit cornea (Sirc) cells. Proc Soc Exp Biol Med, v. 125, p. 127I-4, 1967.

16. WELLER, T. H.; NEVA, F.A. Propagation in tissue culture of cytopathic agents from patients with rubella-like illness. Proc Soc Exp Biol Med, v. II I, p. 215-25, 1962.

17. WOLINSKY, J. S. Rubella in fields virology. $3^{\text {rd }}$ ed. New York: Lippincott-Raven, 1996. p. 899-930. 